\title{
An Analysis of Students' Error in Learning Mathematical Problem Solving: The Perspective of David Kolb's Theory
}

\author{
Widodo Winarso ${ }^{a}$ and Toheri Toheri ${ }^{b}$ \\ ${ }^{a}$ Institut Agama Islam Negeri Syekh Nurjati, Indonesia (ORCID: 0000-0002-8527-7660) \\ ${ }^{\mathbf{b}}$ Institut Agama Islam Negeri Syekh Nurjati, Indonesia (ORCID: 0000-0001-5045-6880)
}

Article History: Received: 17 June 2020; Accepted: 2 January 2021; Published online: 3 February 2021

\begin{abstract}
Schoenfeld and Sloane argued that the main task of mathematics education is to explain students' thought processes in order to improve the quality of mathematics learning. Many students make errors in answering maths tests. It turns out that various types of errors depend on students' learning styles. The focus of this research was to analyze students' errors in solving mathematics problems based on differences in students' learning styles according to David Kolb's theory of experiential learning. The study was conducted at Vocational Middle School in Cirebon-Indonesia. The research used a qualitative research case study approach. The instrument used in this study was the Kolb Learning Style Inventory (KLSI version 3.1), and math tests. For data analysis, this study used triangulation techniques. The four categories of learning orientations were found among 24 students who participated in this study, namely converging, accommodating, assimilating, and diverging. The difference with other studies is that this study focuses on discussing student errors based on learning styles. Each type of learning style was associated with its unique errors. Errors made by divergers were procedural errors and misunderstandings; the assimilators' types of error were procedural and conceptual errors; the convergers' error type was a procedural error; the type of error made by accommodators was a theoretical error. Conceptual errors were caused by a misunderstanding of existing concepts, leading the students to make errors in the answer to math tests. Strategy errors can be encountered by students when they were stuck in the answer to a math test. A procedural error occurred when students used a non-systematic method in completing the test.
\end{abstract}

Keywords: Students' error, learning styles, problem-solving, mathematics

DOI: $10.16949 /$ turkbilmat.753899

\section{Introduction}

Mathematics learning is about concepts and structures of mathematics contained in the material being studied, as well as finding the relationship between ideas and mathematical concepts (Hiebert \& Lefevre, 1986). Furthermore, mathematics learning can also be interpreted as a learning process that actively engages students in building mathematical knowledge (Voigt, 2013). Therefore, the teaching of mathematics is a process of interaction between teachers and students, which implies the development of thinking models and elaboration logic in the mathematics classroom. Such condition is created by teachers with various methods so mathematics learning activities can grow and develop optimally. Students can participate in the learning activities effectively and efficiently.

The direction of improving the quality of mathematical education implies clearly that the current learning objectives refer to students' thinking abilities so that with good thinking skills, students will easily understand and master the mathematical concepts they learn (Schoenfeld \& Sloane, 2016). Therefore, learning mathematics should be more focused on student thinking. Considering how essential mathematics is, while there are many negative perceptions of mathematics. Many students do not like mathematics (Hannover \& Kessels, 2004; Tirta Gondoseputro, 1999). The students assume that mathematics is a less desired lesson. According to survey data, mathematics occupies the third position as the most hated subject by students (Rofalina, 2015). Some components of the causes of the less desired learning mathematics are (1) Learning methods from teachers who are lacking interesting; (2) The solving mathematics story problem is less understood and visualized the purpose of the problem; (3) Learning difficulties and decreased interest in learning, (4) the errors students make in answering math tests (Quilter\& Harper, 1988; Archer, DeWitt \& Dillon, 2014).

Meanwhile, based on data from PISA (The Program for International Student Assessment) in 2015, the performance of Indonesian students is relatively low. Successively, the average Indonesian achievement scores for science, reading, and mathematics is ranked 62,61 , and 63 out of 69 countries evaluated. The rank and the average Indonesian students score do not differ much from previous PISA results in 2012, which are also in the low material mastery group (Stacey, 2015). Based on the data, students' ability to understand mathematics is meagre. Students' skills in solving mathematical problems can be known through tests given in the evaluation of mathematical learning. In the process of mathematics learning, students often make errors. The number of errors made in working on mathematical problems hints at the extent to which students understand the material. From

Corresponding Author: Widodo Winarso (i) email: widodoiain@gmail.com

Citation Information: Winarso, W. \& Toheri, T. (2021). An analysis of students' error in learning mathematical problem solving: The perspective of David Kolb's theory. Turkish Journal of Computer and Mathematics Education, 12(1), 139-150. https://doi.org/10.16949/turkbilmat.753899 
the errors made, the source of errors committed by students can be further investigated. The cause of the errors made by the student should be apparent by analysing the root cause of the errors, and then by identifying the types of errors that are commonly made by students in solving mathematics tests.

The students' ability to understand mathematics is meager. Students' skills in solving mathematical problems can be known through tests given in the evaluation of mathematical learning. In the process of mathematics learning, students often make errors (Warshauer, 2015). The number of errors made in working on mathematical problems hints at the extent to which students understand the material. From the errors made, the source of errors committed by students can be further investigated. The cause of the errors made by the student should be apparent by analysing the root cause of the errors, and then by identifying the types of errors that are commonly made by students in solving mathematics tests. The errors made by students become obstacles to learning mathematics. Students' errors in many mathematical topics are the primary source for knowing the difficulties experienced by students in learning mathematics (Taylor 1999). The teacher needs to identify the types of errors starting from the calculation of operations performed by students and the use of concepts, to the procedure for working on mathematical tests (Mercer \& Mercer, 2019). The types of errors made by students are divided into four categories: operating errors, computational errors, algorithmic errors, and random answers. This is similar to what is explained by Radatz (1980), that there are three indicators of the type of error: a) misunderstandingerrors made by students in using concepts related to the material; b) principle errors-errors in applying mathematical rules or formulas, or misuse of laws relating to content, c) operational errors - errors in operations or calculations. Indeed, students' errors will have an impact on the results of learning process.

Students' low achievement is caused by many things, such as a dense curriculum, ineffective learning media, inappropriate learning strategies and methods chosen by the teacher, a poor evaluation system, a teacher's ability that is less able to arouse students' learning motivation or a conventional learning approach in which students are not much involved in the learning process (Lim \& Morris, 2009). Another factor is students' character in the learning process, as well as learning styles owned by each student. Errors in mathematical problem solving can also be observed from students' learning styles (Ryan \& Williams, 2007). In line with that opinion, Geist and King (2008) argued that students' errors can be seen from student learning styles. As each individual has a different character, students' answers to math tests can be influenced by various factors that can lead students to make various errors in problem-solving.

Learning styles are a combination of how one absorbs and then organises and processes information (Schmeck, 2013). Learning styles are not only aspects of processing information through senses (seeing, listening, speaking as well as writing), but also the element of information processing, or optimisation of leftbrain right-brain, and other aspects regarding responses toward in the mathematics classroom (absorbed abstractly and concretely). This is in line with the statement of Riding and Rayner (2013), which suggests that a student's learning style is the consistent way to capture stimulus or information, how to remember or think and solve problems. So, learning styles are the way students tend to react and use incentives to absorb and then organise and process information in the learning process.

The Learning Style David Kolb's developed is a learning style that involves students' new experiences, develops observation/reflection and drafts, and uses theories to solve problems (Tuyen, 2018). Student learning style is influenced by personality types and habits, and it develops over time and experience. The Learning Style is built on the idea that learning preferences can be explained by the active observations of experimentsreflections and experiences of abstract concrete concepts. The implication is that there are four types of learners regarding their learning styles: converger, accommodator, assimilator, and diverger (Kolb, 1981). The converger also approaches knowledge through abstract conceptualization however the converger favors processing it through active experimentation. Convergers prefer to deal with technical tasks and problems rather than with social and interpersonal issues. Their strength lies in problem solving, decision making, and the practical application of ideas (Geiger, 1992; Kolb, 1984; Kolb, Boyatzis \& Mainemelis, 2001).

Accommodators have the ability to learn from primarily "hands-on" experience. They enjoy carrying out plans and involving themselves in new and challenging experiences. They may tend to act on their "gut" feeling rather than on logical analysis. In solving problems, accommodators rely more heavily on people for information than on their own technical analysis. They tend to be adaptive and risk-taking and perform well in situations where they must change to meet immediate circumstances. They are at ease with people but sometimes can come across as impatient (Kolb, 1984, Kolb, Boyatzis \& Mainemelis, 2001; Geiger, 1992).

The assimilator prefers to approach knowledge through abstract conceptualization and to process it through reflective observation. Assimilators are best at understanding a wide range of information and putting the information into a concise, logical form. Their strength lies in inductive reasoning and the ability to create theoretical models. Assimilators are less focused on people and more interested in ideas and abstract concepts. Generally, assimilators find it more important that a theory have logical soundness than practical value ideas (Kolb, 1984, Kolb, Boyatzis \& Mainemelis, 2001; Geiger, 1992). 
Divergers prefer to approach learning through Concrete Experience (CE) and to process it through Reflective Observation (RO). Divergers are best at viewing existing situations from many different points of view. Individuals perform better in situations requiring generating new ideas and brainstorming. Their strength lies in imaginative ability and awareness of meaning and values. They tend to have broad cultural interests, are interested in people, and are feeling oriented. Accommodators also prefer to take in knowledge through concrete experience, however they favor processing it through active experimentation ideas (Geiger, 1992; Kolb, 1984, Kolb, Boyatzis \& Mainemelis, 2001; Papadopoulos, 2020).

In a preliminary study conducted for this research and based on observations at one of the vocational high schools in Cirebon, many students said they had difficulty understanding mathematical problems. Students' scores on the test do not reflect the level of their understanding of the relationship of mathematical concepts. Some-students tended to maintain wrong conceptions even though the teacher had specifically taught the characteristics of relevant concepts. An approach is needed to analyze students' errors, which include: 1) Material profile approach, which is to an analysis in the material mastering profile. Where the competence of students for sub material compared with competence with other material. 2) Prerequisite knowledge approach, which detects the failure of students for prerequisite knowledge. 3) Approach to achieving basic competencies and indicators, i.e., diagnosing failures in achieving learning objectives and indicators. 4) The error approach concept, namely, to analyze student errors through misconceptions (Chinn, 2020).

In addition to phenomena in the field, several previous studies have examined student errors in completing mathematics tests (Hansen, et al., 2020). Discovering and addressing errors during mathematics problem solving (Granberg, 2016). Errors of students learning with react strategy in solving mathematical representation ability (Sari, et al., 2018). In addition, Suyitno and Suyitno (2015) also examined Learning therapy for students in mathematics communication correctly based on Newman's procedure. Meanwhile, Junaedi, et al. (2015) disclosure the causes of student's errors in resolving discrete mathematics problems based on NEA as a means of enhancing Creativity. Researchers are interested in studying students' errors in learning mathematical problem solving from the perspective of David Kolb's theory.

The mathematics teacher believed that students had various learning styles that were unidentified, which corresponds to the learning process carried out in the class. Thus, the researchers were interested in discussing David Kolb's theory about learning styles, in which individual differences are mapped into different types of learning styles. Observing the problem, previous studies have not paid attention to the analysis of students' errors based on differences in students' learning styles. Moreover, the analysis of students' errors in solving mathematical problems can be detected through their answers to test questions. Thus, the researchers were encouraged to analyze students' errors.

\section{Method}

This section is compulsory, and it should provide a specific description of the methodology. All descriptions of materials and methods should be included here in the main paper. It should have the following structure.

Based on this study's objectives, namely to analyze student errors, the type of research used was a qualitative study with a case study approach (Creswell \& Creswell, 2017; Taylor et al., 2015). This research approach was chosen because it was carried out systematically; it can help the researchers figure out the issue of this study as it can provide a specific description of students' errors in learning mathematics in school. The flowchart of case study research carried out is as presented in Figure 1.

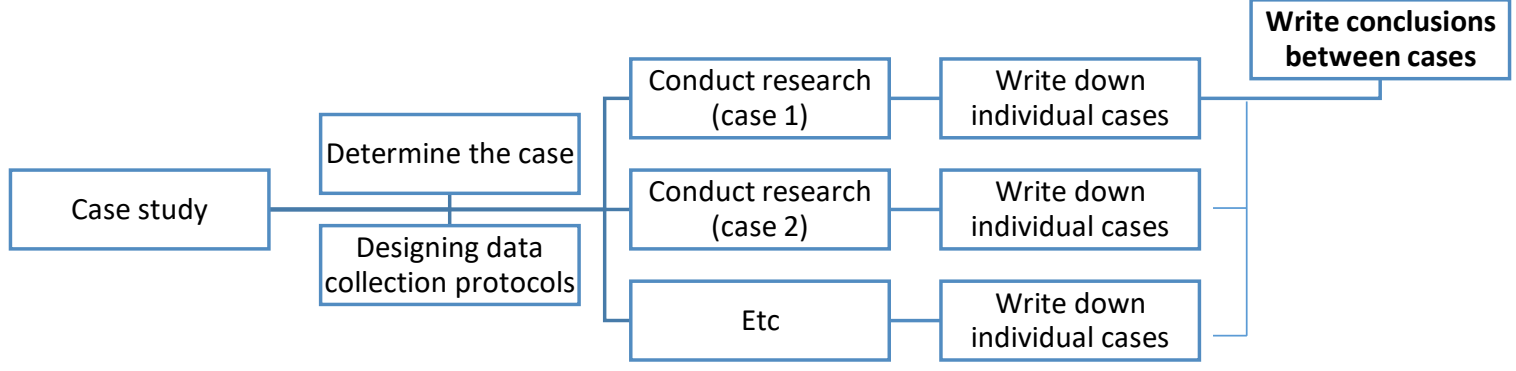

Figure 1. Research flowchart in case studies

\subsection{Procedure}

This research was conducted at SMK Patriot, a Vocational Middle School in Cirebon-Indonesia. The participants in this study were 24 of 10th grade students, grouped by the four learning styles proposed by David 
Kolb. Then randomly selected from each representation of the learning style by using the Quota sampling technique (Etikan \& Bala, 2017). The selection of participants was based on the following criteria: a) students who completed the mathematics test with the most questions $(n=16)$ and $b)$ students who made the more errors in working on mathematics problems $(n=8)$. The object of the research was to understand why the students made errors in mathematics problems. The topic of the mathematics test was the system of linear equations with two variables (SPLDV).

\subsection{Data collection and analysis technique}

The instruments used in this study were questionnaires and tests. Both the questionnaire and the test tools were created and developed by the researcher. The questionnaire development process adopted the Kolb Learning Style Inventory concept and referred to KLSI version 3.1 (Kolb, 1976; Manolis et al., 2013). Then adjusted to students' characteristical of thinking and language in vocational middle school. The 12 items represented the dimension of CE (Concrete Experience), 12 items described the aspect of RO (Reflective Observation), 12 items described the dimension of AC (Abstract Conceptualisation), and 12 items represented the aspect of $\mathrm{AE}$ (Active Experimental). The indicators can be seen in the following table 1.

Tabel 1. Learning style indicators in the David Kolb theory

\begin{tabular}{|c|c|}
\hline Learning Style & Indicator \\
\hline $\begin{array}{l}\text { Diverger } \\
(\mathrm{CE} \text { and } \mathrm{RO})\end{array}$ & $\begin{array}{l}\text { - } \text { Learn to rely on feelings } \\
\text { - } \text { Study in groups } \\
\text { - } \text { Be open to other people } \\
\text { - } \text { Learn from observation } \\
\text { - } \quad \text { Thorough in learning } \\
\text { - } \quad \text { Careful in listening to the meaning } \\
\text { - } \quad \text { Learn in many ways }\end{array}$ \\
\hline $\begin{array}{l}\text { Assimilator } \\
\text { (RO and AC) }\end{array}$ & $\begin{array}{l}\text { - } \text { Learn from observation } \\
\text { - } \quad \text { Thorough in learning } \\
\text { - } \quad \text { Careful in listening to the meaning } \\
\text { - } \quad \text { Learn in many ways } \\
\text { - } \quad \text { Think logically } \\
\text { - } \quad \text { Behave in theory } \\
\text { - } \text { Make preparations before studying } \\
\text { - } \quad \text { Likes analytical }\end{array}$ \\
\hline $\begin{array}{l}\text { Converger } \\
\text { (AC and AE) }\end{array}$ & $\begin{array}{l}\text { - } \text { Think logically } \\
\text { - } \quad \text { Behave in theory } \\
\text { - } \text { Make preparations before studying } \\
\text { - } \quad \text { Likes analytical } \\
\text { - } \text { Complete tasks independently } \\
\text { - } \text { Active in learning } \\
\text { - } \quad \text { Learning through practice } \\
\text { - } \quad \text { Carry out duties by the provisions }\end{array}$ \\
\hline $\begin{array}{l}\text { Accommodator } \\
\text { (AE and CE) }\end{array}$ & $\begin{array}{l}\text { - } \text { Complete tasks independently } \\
\text { - } \text { Active in learning } \\
\text { - } \text { Learning through practice } \\
\text { - } \text { Carry out duties by the provisions } \\
\text { - } \quad \text { Learn to rely on feelings } \\
\text { - } \quad \text { Study in groups } \\
\text { - } \text { Be open to other people }\end{array}$ \\
\hline
\end{tabular}

While the test used in this study was an essay test (Mohamad et al., 2015), the grid for the evaluation of the essay analysed the achievement of the learning of the system of linear equations with two variables (SPLDV). The reference used in the preparation of this essay test adopted the cognitive aspects of Bloom's taxonomy, namely the categories C3 (analyze), C4 (apply), C5 (understand), and C6 (remember) (Bloom, 1956), as set out in Table 2 below. The essay test used five indicators spread over six items. For data analysis, this study used the triangulation technique (Leech \& Onwuegbuzie, 2007).

The essay test used by previous researchers was tested first. The number of questions used as a trial was 9 items, where every 2 items represented one indicator. The trial test is carried out once. The previous essay test was tested for the validity of its contents first by an expert validator. Next carried out in the content validation test regarding the suitability of the questions with indicators and assessment in terms of language. 
After validation, the next step is to analyze the test-equipment. Analysis of the test equipment aims to identify good, bad, and bad questions. So that information is obtained, which will be used to perfect the questions for further purposes. The test analysis used is with Anates V4 software, while the test analysis includes the validity of the items and reliability.

The validity of the items is based on the results of the calculation of $r_{\text {count }}>r_{\text {table }}$, so the questions are declared valid. If the results of data analysis on item $r_{\text {count }}<r_{\text {table }}$ then the question is declared invalid. From the calculation results, it is found that out of 9 items, 6 items are stated as valid. The results of the reliability calculation show $\mathrm{r}=0.69$ so that the test questions are questions that have a reliable.

Table 2. Essay Test Indicator.

\begin{tabular}{|c|c|c|c|c|c|c|}
\hline \multirow{2}{*}{ Indicator } & \multicolumn{6}{|c|}{ Cognitive aspects-Item } \\
\hline & $\mathrm{C} 1$ & $\mathrm{C} 2$ & C3 & $\mathrm{C} 4$ & $\mathrm{C} 5$ & C6 \\
\hline $\begin{array}{l}\text { Students can determine the completion of a two-variable } \\
\text { linear equation system. }\end{array}$ & & & 1 & & & \\
\hline $\begin{array}{l}\text { Students can work on problems well related to the } \\
\text { completion of the system of two-variable linear equations. }\end{array}$ & & & & 2 & & \\
\hline $\begin{array}{l}\text { Students can identify problems related to systems of linear } \\
\text { equations. }\end{array}$ & & & & & 3 & \\
\hline $\begin{array}{l}\text { Students can interpret the results of problem-solving related } \\
\text { to the two-variable linear equation system. }\end{array}$ & & & & & 4 & \\
\hline $\begin{array}{l}\text { Students can make mathematical models related to systems } \\
\text { of linear equations. }\end{array}$ & & & & & & 5,6 \\
\hline
\end{tabular}

Triangulation techniques include interviews, and results work of the subject. The analysis steps of the research data include; data reduction, data display, conclusion drawing/verification. To find out the student's error can be observed through the results of the test. In addition, to in-depth interviews about how it works. This needs to be done to observe the causes of student errors. In this study, the researchers conducted observations using a handphone to record the results of work and interview. This was done so that each data from work and interview well collected.

\section{Findings and Discussion}

The first stage of this study was classifying students' learning styles. Based on the results of the Kolb Learning Style Inventory (KLSI) survey of 24 10th grade students of Cirebon Patriot State Vocational School, the grouping of learning styles was obtained as follows.

Table 3. The Proportion of Students' Learning Styles.

\begin{tabular}{lcc}
\hline Type of learning style & $\begin{array}{c}\mathbf{n} \\
(\boldsymbol{\%})\end{array}$ & Subject code \\
\hline Diverger & $\mathrm{n}=3$ & PM04, PM18, PM19 \\
& $(12.5)$ & \\
Assimilator & $\mathrm{n}=4$ & PM01, PM11, PM14, PM22 \\
& $(16,7)$ & \\
Converger & $\mathrm{n}=8$ & PM02, PM03, PM05, PM07, PM09, PM16, PM20, PM21 \\
& $(33.3)$ & \\
Accommodator & $\mathrm{n}=9$ & PM6, PM8, PM10, PM12, PM13, PM15, PM17, PM23, PM24 \\
& $(37.5)$ & \\
\hline
\end{tabular}

Based on Table 3, the accommodator type was more dominant than others (37.5\% of students), while the percentage of diverger type was the smallest compared to the three other learning styles (12.5\% of students). After classifying students based on the Kolb learning style, only a total of eight participants were eligible for further analysis. Subject selection of research, based on two representations of each learning style. This is in accordance with the quota collection technique (Etikan \& Bala, 2017). They were given a mathematics test to find out what kind of errors occurred. The following was the second stage of this study, which was dissecting several cases of errors made by students based on differences in their learning styles. 
Table 4. Characteristics of Students' Errors in Learning Mathematical Problem Solving.

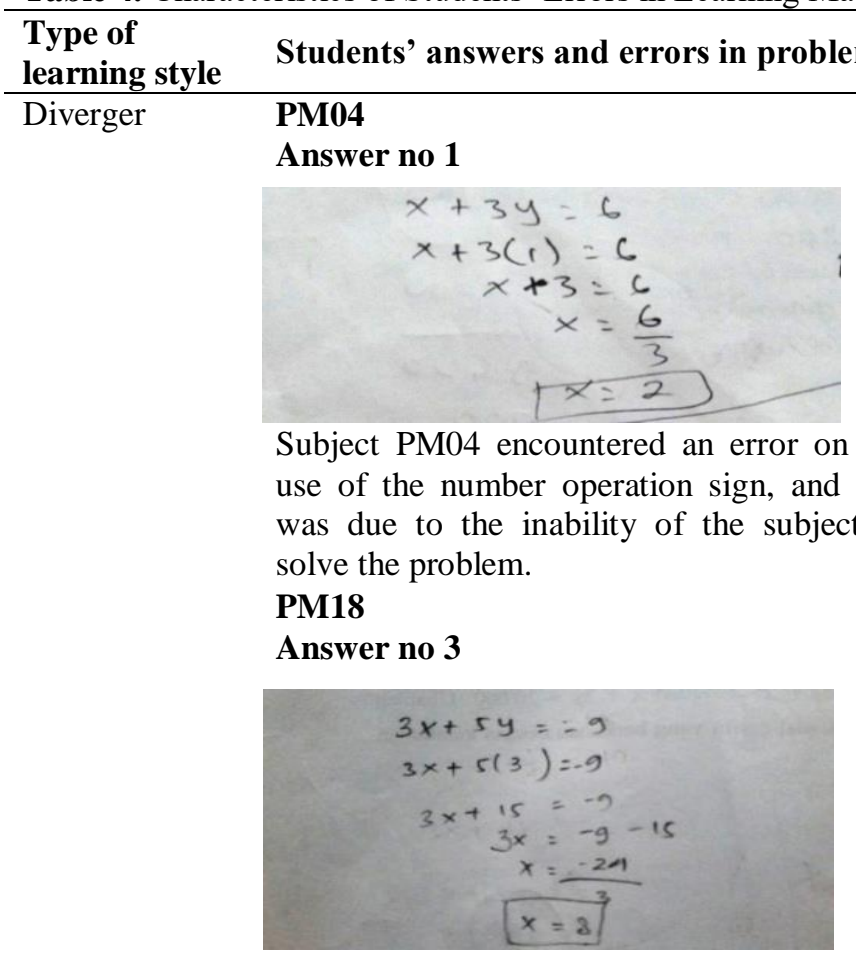

Subject PM18 performed an error on number operation.

\begin{tabular}{|c|c|}
\hline \multirow[t]{2}{*}{ Assimilator } & $\begin{array}{l}\text { PM01 } \\
\text { Answer no } 4\end{array}$ \\
\hline & 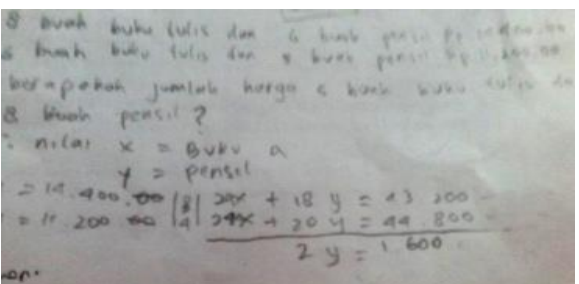 \\
\hline
\end{tabular}

Subject PM01 made a mistake in that they did not work the problem completely.

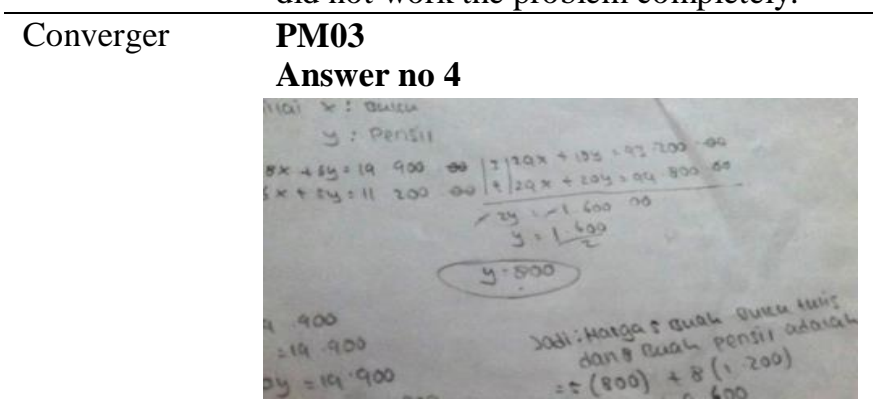

Subject PM03 performed an error in placing variable $\mathrm{x}$ and $\mathrm{y}$.

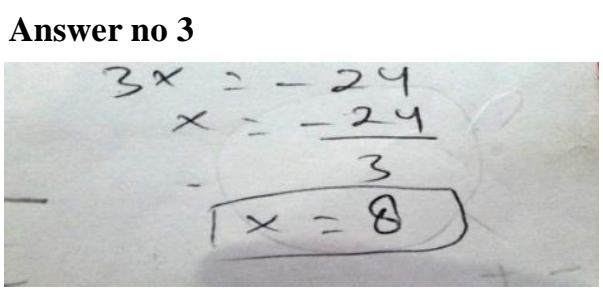

Subject PM04 also performed procedural errors in terms of the division of positive and negative numbers.

\section{Answer no 6}

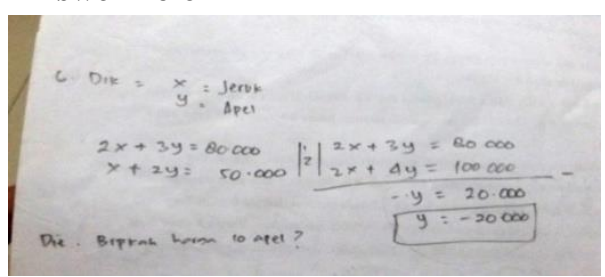

Subject PM18 had two operations counting errors in integers.

\section{PM22}

Answer no 4

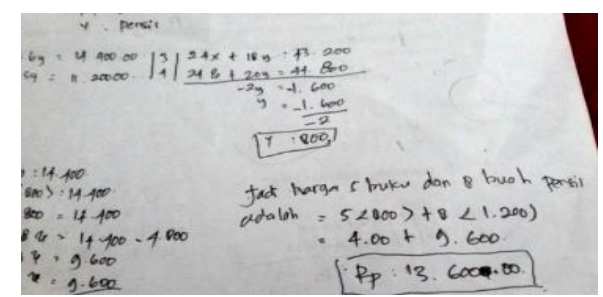

Subject PM22 made an error in placing the variable.

\section{Answer no 6}

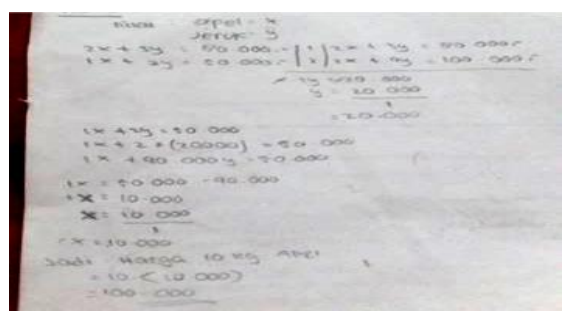

Subject PM03 made an error in determining the variables $\mathrm{x}$ and $\mathrm{y}$. 


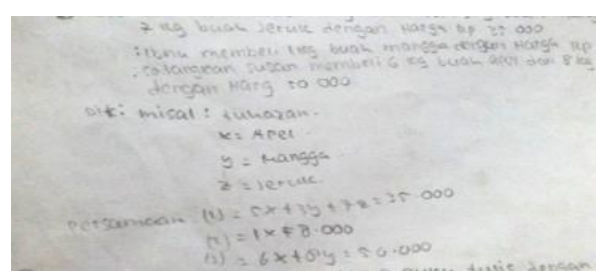

Answer no 8

PM07

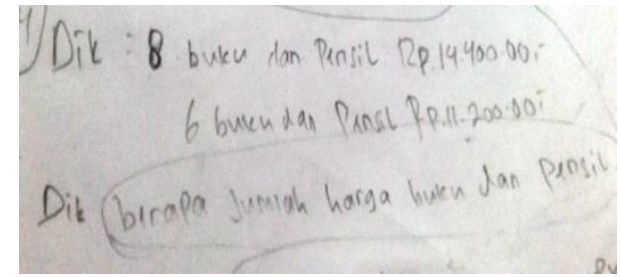

Answer no 4
Subject PM03 made a mistake in transforming the story into a mathematical modelling.

Subject PM07 made an error in not completing the work and also made a redaction error.

\section{Accommodator PM08}

\section{Answer no 4}

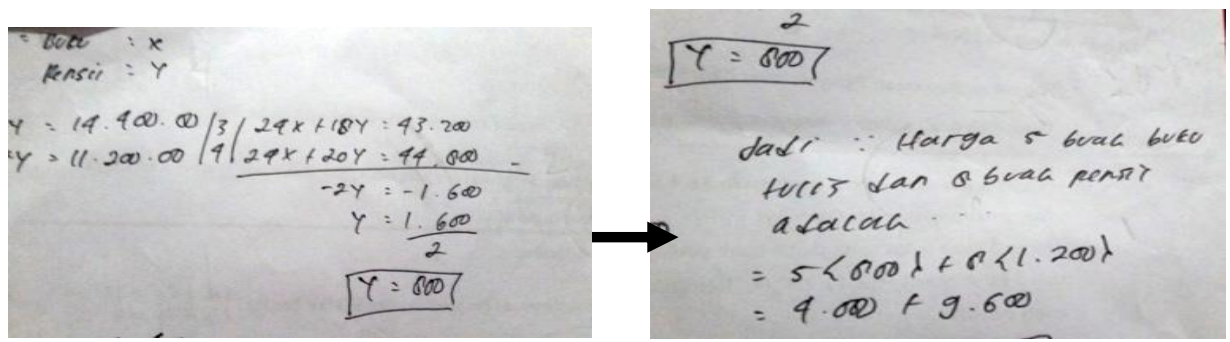

Subject PM08 had errors in the procedure of entering the data given.

\section{PM24}

\section{Answer no 6}

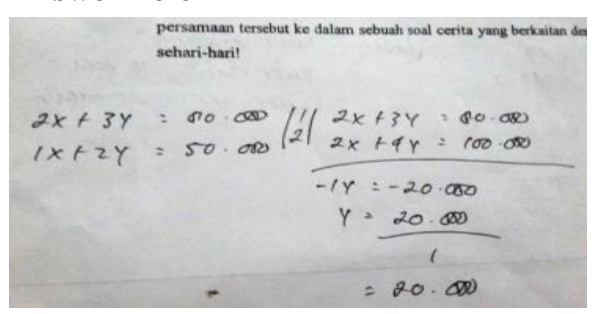

Subject PM24 made an error in not continuing with the work.

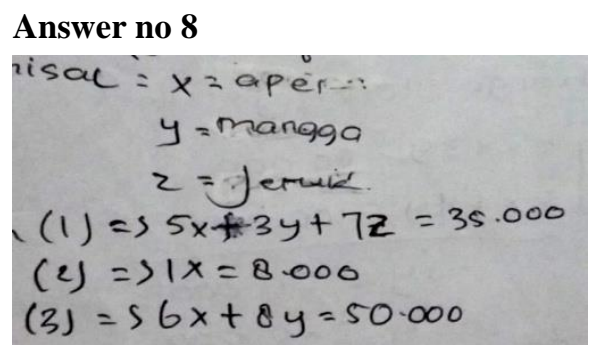

Subject PM24 made an error in placing the variable.

The study continued to the third stage, namely classifying the types of students' errors by referring to the result of the previous stage in Table 3. The explanation below described the students' type of error and provided an example of the factors that led to students' errors.

Type of conceptual error: The first type of error students made was a conceptual error. According to Hiebert and Lefevre (1986), a conceptual error is a mistake in determining and using the theorem to answer a problem. Correspondingly, Riccomini ( 2005) explains that conceptual error indicators include: a) incorrectly determining the formula or theorem or definition to answer the problem; b) incorrect use of formulas, theorems or definitions which are inconsistent with the conditions under which formulas, theorems or definitions apply; and c) incorrectly writing formulas, theorems or definitions to answer the problem.

The subjects who made conceptual errors were PM08, PM22 and PM24. Subject PM08 made the mistake of not changing the given information to the definition to make it easier for the next stage. Subjects PM08, PM22 
and PM24 created mathematical equations without any variables. This led the subject to not complete the work. Based on the interview, the subject did not quite understand that he made a mistake. Subject PM22 misinterpreted problem number 4 . The participant's answer did not match the existing or taught definition. Interview results stated that the concept known to the subject is a searched variable first. But the idea is wrong, so the subject made a mistake.

This case also occurred with subject PM24. The subject did not understand the existing material and created his own theory based on his feelings. The subject made an error when turning the mathematics story problems into mathematical modelling. In the interview, he argued that the variable of an equation should start from the variable (x) without considering the information given in the problem or regardless of the occupation that has been occupied. Because of the subject's misconception, he made errors. This is in line with the results of research Cawley, Parmar, Foley, Salmon, and Roy (2001) states that large numbers of students of all ages fail to demonstrate grade-level proficiency in solving story problems. Solving story problems is often difficult because it requires both reading comprehension and mathematics skills as well as the ability to transform words and numbers into the appropriate operations (Neef, Nelles, Iwata \& Page, 2003).

In summary, conceptual errors are made because of incorrect understanding or irrelevant understanding from the existing provisions, so this causes a person to make errors in the process of solving problems. The indicators of conceptual errors are a) wrong in changing the problem into a mathematical equation and b) false in using data (Hidayat \& Iksan, 2015; Herholdt \& Sapire, 2014; Riccomini, 2005).

Based on the description above, the relationship of learning styles with conceptual errors made by students can be identified as follows in Table 5 .

Table 5. Relationship of Learning Styles to the Types of Conceptual Errors

\begin{tabular}{lll}
\hline Student & Learning style & Types of conceptual errors \\
\hline PM08 & Accommodator & Defining unclear variables \\
PM22 & Assimilator & Defining unclear variables \\
PM24 & Accommodator & Understanding of mathematical model as an equation \\
\hline
\end{tabular}

Students with accommodator learning styles pay less attention to the logical relationship among variables. This tendency results in the difficulty of types of accommodative learning styles in arranging logical relationships between variables and explaining the meaning of variables logically. In this type of learning style, the dominance of intuition affects the logical framework in the subject's thinking, whereas the interest in abstract matters becomes an obstacle for type assimilator. The difficulty the subject experienced was translating and defining the context of information into variables. The subject did not understand the correlation between the context problem and the variables he worked on thus he made an error in entering the value of the variables.

Type of strategy error: The second type of error students make is a strategic error. According to Jordan \& Montani (1997), a strategy error is an error that occurs if the student chooses an inappropriate direction which leads to a deadlock path. This is related to what Watson (1980) said, that the category of errors in problems is related to the question of the hierarchy of skills.

Subject PM18 made a strategy error on operation number, where the answer obtained results for apple unit price is Rp. (-) 20,000. The subject is aware of the error because no rupiah value is negative. But the subject does not have the motivation to re-check, so, with the beginning of the process wrong, the subject experiences deadlock. The subject prefers not to solve the problem where it affects the final result. Thus, a strategy error is an error in the process experienced by someone in a deadlock who is continuing the settlement process (Pugalee, 2004; Montague, Warger \& Morgan, 2000).

PM18, with his diverger learning style, ignored the sign (-) in doing his calculations. His interest in seeing situations with a variety of perspectives and the use of feelings resulted in his lack of attention to small things, such as the sign (-) in the calculation of answers. The context of fruit and price is more attractive to him than the sign (-) in mathematical operations.

Type of procedural error: The third type of error students make is a procedural error. A procedural error is an error in preparing the steps (O'Connell, 1999). Further explained, procedural error indicators are: a) wrong not writing the problem in process of settlement, b) incorrectly discontinuing the settlement process, c) wrong in understanding and observing the purpose of the question, d) wrong in performing addition and subtraction operations, e) wrong in multiplication and distribution operations, f) unable to manipulate steps, g) unable to draw conclusions with reason, and h) incorrect because the settlement step is not systematic (Rittle-Johnson \& Alibali, 1999).

Subjects who made procedural errors were PM01, PM03, PM04 and PM07. Subject PM01 encountered an error because they did not complete until the final process. The subject understood concepts and solutions but 
did not solve them due to environmental factors (disturbed concentration). Still, this has an impact on errors in solving a problem. Subject PM03 made a mistake in placing the variables (x) and (y). This is because the subject still does not understand the complex material.

Subject PM04 makes an error in the operation of integers. Of the two questions resolved by the subject, both are the same type of error which was caused by others around him making him unable to focus.

Subject PM07 had an error in looking at the problem. The information written by PM07 does not match what was asked in the question. This was due to the subject's physical condition which lead him to make a mistake in figuring out what was known and what was asked in the problem (Jaber, Givi \& Neumann, 2013).

Thus, a procedural error is an error in using an unsystematic way to perform a settlement that affects the outcome. The procedural error indicator is a) wrong not writing down what is known and asked, b) wrong not solving the problem to the end, c) incorrect in the placement of known data, d) wrong in counting operations that impact on the final result.

Based on the description above, the relationship between learning styles and procedural errors made by students can be identified as follows.

Table 6. Relationship of Learning Styles to the Types of Procedure Errors

\begin{tabular}{lll}
\hline Student & Learning style & Types of conceptual errors \\
\hline PM01 & Assimilator & The completion procedure was not completed. \\
PM03 & Converger & $\begin{array}{l}\text { Inappropriate substitution, the omission of the sign (-) } \\
\text { in the settlement procedure. }\end{array}$ \\
PM04 & Diverger & Procedure for subtracting and dividing integers. \\
PM07 & Converger & Does not understand what to do to solve the problem. \\
\hline
\end{tabular}

The type of assimilator, interest in thinking, and observing are factors in the emergence of doubt in taking action (Peker, 2009). The stages/steps that must be passed in solving mathematical problems become obstacles for them. They were not confident and unsure of the procedures that should be followed thus making them reconsider and re-observe the procedures. Hence, they were running out of time to solve the problem.

The type of converger who likes to think and act has no difficulty in solving mathematical equations (Orhun, 2007). However, the context of the problem becomes their difficulty in solving it. They tend to pay less attention to the context they create themselves in a variable that they define.

This type of diverger does not pay much attention to procedural solutions (Peker \& Mirasyedioğlu, 2008; Orhun, 2007). Example of errors made by the divergers in solving problems were mistaken in using multiplication procedure in addition problem and ignoring negative sign (-) in the division of integers.

\section{Conclusion and Suggestions}

Based on the findings presented, it can be concluded that the types of errors made are related to student learning styles. Divergers tend to experience strategic errors. The error of the strategy is to ignore the sign (-) in doing the calculations, while the procedural error is in the procedure of subtracting and dividing integers. Assimilators tend to make conceptual errors and procedural errors. The conceptual errors that the subject experienced was the definition of an unclear variable, while the procedural error was that the complete procedure was not completed. Accommodators tend only to experience conceptual errors. Conceptual errors are about defining unclear variables and mathematical models as an equation. On the other side, convergers tend to make procedural errors such as incorrect substitution, missing negative sign (-) in the solution process, and inability to understand what to do to solve the problem.

Procedural errors tend to be made by students with converger, accommodator and diverger learning styles. Students have difficulty in solving mathematics story problems. They often commit procedural errors in such problems. Mathematical definition and modelling of story problems become a big obstacle for students in solving word problems, especially for students with assimilator and accommodator learning styles. Errors made by students in solving word problems vary, such as defining unclear variables and making incorrect modelling. Those errors lead students to do procedural errors in solving the problems. Diverse errors of the types of learning styles show that each learning style has advantages and disadvantages in solving math problems.

Collaborative learning with group discussions consisting of various types of learning styles is strongly recommended in solving mathematical problems in the form of word problems. Sharing ideas from every kind of learning style can complement each other to produce alternative solutions following the context of the problem at hand. 


\section{References}

Archer, L., DeWitt, J., \& Dillon, J. (2014). 'It didn't really change my opinion': exploring what works, what doesn't and why in a school science, technology, engineering and mathematics careers intervention. Research in Science \& Technological Education, 32(1), 35-55. https://doi.org/10.1080/02635143.2013.865601

Bloom, B. S. (1956). Taxonomy of educational objectives. McKay.

Cawley, J., Parmar, R., Foley, T. E., Salmon, S., \& Roy, S. (2001). Arithmetic performance of students: Implications for standards and programming. Exceptional Children, 67(3), 311-328. https://doi.org/10.1177/001440290106700302

Chinn, S. (2020). More trouble with maths: A complete manual to identifying and diagnosing mathematical difficulties. Routledge.

Creswell, J. W., \& Creswell, J. D. (2017). Research design: Qualitative, quantitative, and mixed methods approaches. Sage.

Etikan, I., \& Bala, K. (2017). Sampling and sampling methods. Biometrics \& Biostatistics International Journal, 5(6), 00149. http://dx.doi.org/10.15406/bbij.2017.05.00149

Geiger, M. A. (1992). Learning styles of introductory accounting students: An extension to course performance and satisfaction. The Accounting Educators' Journal, 4(1), 22-39.

Geist, E. A., \& King, M. (2008). Different, not better: Gender differences in mathematics learning and achievement. Journal of Instructional Psychology, 35(1), 43-52.

Granberg, C. (2016). Discovering and addressing errors during mathematics problem-solving-A productive struggle?. The Journal of Mathematical Behavior, 42, 33-48. https://doi.org/10.1016/j.jmathb.2016.02.002

Hannover, B., \& Kessels, U. (2004). Self-to-prototype matching as a strategy for making academic choices. Why high school students do not like math and science. Learning and Instruction, 14(1), 51-67. https://doi.org/10.1016/j.learninstruc.2003.10.002

Hansen, A., Drews, D., Dudgeon, J., Lawton, F., \& Surtees, L. (2020). Children's errors in mathematics. Learning Matters.

Herholdt, R., \& Sapire, I. (2014). An error analysis in the early grades mathematics-A learning opportunity?.South African Journal of Childhood Education, 4(1), 43-60. https://doi.org/10.4102/sajce.v4i1.46

Hidayat, R., \& Iksan, Z. H. (2015). The Effect of Realistic Mathematic Education on Students' Conceptual Understanding of Linear Progamming. Creative Education, 6(22), 2438-2445. http://dx.doi.org/10.4236/ce.2015.622251

Hiebert, J., \& Lefevre, P. (1986). Conceptual and procedural knowledge in mathematics: An introductory analysis. In J. Hiebert (Ed.), Conceptual and procedural knowledge: The case of mathematics 2 (pp. 1-27). Routledge. https://doi.org/10.4324/9780203063538

Jaber, M. Y., Givi, Z. S., \& Neumann, W. P. (2013). Incorporating human fatigue and recovery into the learning-forgetting process. Applied Mathematical Modelling, 37(12-13), 7287-7299. https://doi.org/10.1016/j.apm.2013.02.028

Jordan, N. C., \& Montani, T. O. (1997). Cognitive arithmetic and problem solving: A comparison of children with specific and general mathematics difficulties. Journal of Learning Disabilities, 30(6), 624-634. https://doi.org/10.1177/002221949703000606

Junaedi, I., M., Suyitno, A., M., Endang Sugiharti, I. U., \& Eng, C. K. (2015). Disclosure Causes of Students Error in Resolving Discrete Mathematics Problems Based on NEA as A Means of Enhancing Creativity. International Journal of Education, 7(5), 31-42. https://doi.org/10.5296/ije.v7i4.8462

Kolb, D. A. (1976). Learning style inventory technical manual. McBer.

Kolb, D. A. (1981). Learning styles and disciplinary differences. In A. W. Chickering (Ed.), The modern American college (pp. 232-255). The Modern American College.

Kolb, D. A. (1984). Experience as the source of learning and development. Upper Sadle River: Prentice Hall.

Kolb, D. A., Boyatzis, R. E., \& Mainemelis, C. (2001). Experiential learning theory: Previous research and new directions. Perspectives on thinking, learning, and cognitive styles, 1(8), 227-247. https://doi.org/10.4324/9781410605986-9

Leech, N. L., \& Onwuegbuzie, A. J. (2007). An array of qualitative data analysis tools: A call for data analysis triangulation. School Psychology Quarterly, 22(4), 557-584. https://doi.org/10.1037/1045-3830.22.4.557

Lim, D. H., \& Morris, M. L. (2009). Learner and instructional factors influencing learning outcomes within a blended learning environment. Journal of Educational Technology \& Society, 12(4), 282-293. Retrieved from https://www.jstor.org/stable/jeductechsoci.12.4.282

Manolis, C., Burns, D. J., Assudani, R., \& Chinta, R. (2013). Assessing experiential learning styles: A methodological reconstruction and validation of the Kolb Learning Style Inventory. Learning and Individual Differences, 23(1), 44-52. https://doi.org/10.1016/j.lindif.2012.10.009

Mercer, C. D., \& Mercer, A. R. (2019). Teaching students with learning problems. University of Toronto Press. 
Mohamad, M. M., Sulaiman, N. L., Sern, L. C., \& Salleh, K. M. (2015). Measuring the validity and reliability of research instruments. Procedia-Social and Behavioral Sciences, 204, 164-171. https://doi.org/10.1016/j.sbspro.2015.08.129

Montague, M., Warger, C., \& Morgan, T. H. (2000). Solve it! Strategy instruction to improve mathematical problem solving. Learning Disabilities Research \& Practice, 15(2), 110-116. https://doi.org/10.1207/sldrp1502_7

Neef, N. A., Nelles, D. E., Iwata, B. A., \& Page, T. J. (2003). Analysis of precurrent skills in solving mathematics story problems. Journal of Applied Behavior Analysis, 36(1), 21-33. https://doi.org/10.1901/jaba.2003.36-21

O'Connell, A. A. (1999). Understanding the nature of errors in probability problem-solving. Educational Research and Evaluation, 5(1), 1-21. https://doi.org/10.1076/edre.5.1.1.3887

Orhun, N. (2007). An investigation into the mathematics achievement and attitude towards mathematics with respect to learning style according to gender. International Journal of Mathematical Education in Science and Technology, 38(3), 321-333. https://doi.org/10.1080/00207390601116060

Peker, M. (2009). Pre-Service teachers' teaching anxiety about mathematics and their learning styles. Eurasia Journal of Mathematics, Science \& Technology Education, 5(4). 335-345. https://doi.org/10.12973/ejmste/75284

Peker, M., \& Mirasyedioğlu, Ş. (2008). Pre-service elementary school teachers' learning styles and attitudes towards mathematics. Eurasia Journal of Mathematics, Science \& Technology Education, 4(1), 21-26. https://doi.org/10.12973/ejmste/75302

Pugalee, D. K. (2004). A comparison of verbal and written descriptions of students' problem solving processes. Educational Studies in $\quad$ mathematics, 55(1-3), $27-47$. https://doi.org/10.1023/b:educ.0000017666.11367.c7

Quilter, D., \& Harper, E. (1988). Why we didn't like mathematics, and why we can't do it. Educational research, 30(2), 121-134. https://doi.org/10.1080/0013188880300206

Papadopoulos, I. (2020). Using tasks to bring challenge in mathematics classroom. Journal of Pedagogical Research, 4(3), 375-386.

Radatz, H. (1980). Students' errors in the mathematical learning process: A survey. For the Learning of Mathematics, 1(1), 16-20. https://www.jstor.org/stable/40247696

Riccomini, P. J. (2005). Identification and remediation of systematic error patterns in subtraction. Learning Disability Quarterly, 28(3), 233-242. https://doi.org/10.2307/1593661

Riding, R., \& Rayner, S. (2013). Cognitive styles and learning strategies: Understanding style differences in learning and behavior. David Fulton.

Rittle-Johnson, B., \& Alibali, M. W. (1999). Conceptual and procedural knowledge of mathematics: Does one lead to the other? Journal of Educational Psychology, 91(1), 175-189. https://doi.org/10.1037/00220663.91.1.175

Rofalina, F. (2015). Infografik: Pelajaran paling disukai dan dibenci siswa Indonesia. https://www.zenius.net/blog/7657/pelajaran-disukai-dibenci-siswa

Ryan, J., \& Williams, J. (2007). Children's mathematics 4-5: Learning from errors and misconceptions. McGraw-Hill Education.

Sari, D. P., Darhim, D., \& Rosjanuardi, R. (2018). Errors of students learning with react strategy in solving the problems of mathematical representation ability. Journal on Mathematics Education, 9(1), 121-128. https://doi.org/10.22342/jme.9.1.4378.121-128

Schmeck, R. R. (2013). Learning strategies and learning styles. Springer Science \& Business Media.

Schoenfeld, A. H. (2016). Learning to think mathematically: Problem solving, metacognition, and sense making in mathematics. Journal of Education, 196(2), 1-38. https://doi.org/10.1177/002205741619600202

Schoenfeld, A. H., \& Sloane, A. H. (2016). Mathematical thinking and problem solving. Routledge.

Stacey, K. (2015). The international assessment of mathematical literacy: PISA 2012 framework and items. In S. J. Cho (Ed.), The 12th International Congress on Mathematical Education (pp. 771-790). Springer. https://doi.org/10.1007/978-3-319-17187-6_43

Suyitno, A., \& Suyitno, H. (2015). Learning therapy for students in mathematics communication correctly based-on application of Newman procedure (a case of Indonesian student). International Journal of Education and Research, 3(1), 529-538.

Taylor, N., Clay-Williams, R., Hogden, E., Braithwaite, J., \& Groene, O. (2015). High performing hospitals: A qualitative systematic review of associated factors and practical strategies for improvement. BMC Health Services Research, 15(1), 244. https://doi.org/10.1186/s12913-015-0879-Z

Taylor, S. J., Bogdan, R., \& DeVault, M. (1999). Introduction to qualitative research methods: A guidebook and resource. The Journal of Nervous \& Mental Disease, 187(9), 587. https://doi.org/10.1097/00005053199909000-00011

Tirta Gondoseputro, T. (1999). The cross-cultural perspective of teachers' beliefs and their influence on teaching practices: A case study of two teachers teaching secondary mathematics in Australia and Indonesia. In J. M. 
Truran \& K. M. Truran (Eds.), Making the difference: Proceedings of the twenty-second annual conference of the mathematics education research group of Australasia incorporated (pp. 494-501). The Mathematics Education Research Group of Australasia Incorporated.

Tuyen, N. H. (2018). The Process of Approaching and Implementing Experiential Learning for Teaching Maths to Junior Secondary School Students in Viet Nam. American Journal of Educational Research, 6(6), 877882. https://doi.org/10.12691/education-6-6-42

Voigt, J. (2013). Negotiation of mathematical meaning in classroom processes: Social interaction and learning mathematics. In L. P. Steffe, P. Nesher, P. Cobb, B. Sriraman, B. Greer (Eds.), Theories of mathematical learning (pp. 33-62). Routledge. https://doi.org/10.1007/978-94-017-2057-1_6

Warshauer, H. K. (2015). Productive struggle in middle school mathematics classrooms. Journal of Mathematics Teacher Education, 18(4), 375-400. https://doi.org/10.1007/s10857-014-9286-3

Watson, I. (1980). Investigating errors of beginning mathematicians. Educational Studies in Mathematics, 11(3), 319-329. https://doi.org/10.1007/BF00697743 